\title{
GRIN2B encephalopathy: novel findings on phenotype, variant clustering, functional consequences and treatment aspects
}

\author{
A full list of authors and affiliations appears at the end of the article.
}

\begin{abstract}
Background-We aimed for a comprehensive delineation of genetic, functional and phenotypic aspects of GRIN2B encephalopathy and explored potential prospects of personalised medicine.

Methods-Data of 48 individuals with de novo GRIN2B variants were collected from several diagnostic and research cohorts, as well as from 43 patients from the literature. Functional consequences and response to memantine treatment were investigated in vitro and eventually translated into patient care.
\end{abstract}

Results-Overall, de novo variants in 86 patients were classified as pathogenic/likely pathogenic. Patients presented with neurodevelopmental disorders and a spectrum of hypotonia, movement disorder, cortical visual impairment, cerebral volume loss and epilepsy. Six patients presented with a consistent malformation of cortical development (MCD) intermediate between tubulinopathies and polymicrogyria. Missense variants cluster in transmembrane segments and ligand-binding sites. Functional consequences of variants were diverse, revealing various potential gain-of-function and loss-of-function mechanisms and a retained sensitivity to the use-dependent blocker memantine. However, an objectifiable beneficial treatment response in the respective patients still remains to be demonstrated.

Conclusions-In addition to previously known features of intellectual disability, epilepsy and autism, we found evidence that GRIN $2 B$ encephalopathy is also frequently associated with movement disorder, cortical visual impairment and MCD revealing novel phenotypic consequences of channelopathies.

Correspondence to: Dr Johannes R Lemke, Institute of Human Genetics, University of Leipzig, Leipzig, Germany; johannes.lemke@medizin.uni-leipzig.de.

Web resource

For the ExAC database, see: http://exac.broadinstitute.org

Contributors KP, HOY, BIL, SFT, JRL conceived the project. KP, KLH, ST, MCW, BTT, DJA, CD, BK, CM, EF, SB, DD, TMS, HCM, CTM, AMM, AL, LS, IES, EB, LAB, RSM, UBJ, JJM, ATB, EMG, IDB, SF, PM, JRJ, EHZ, RAJ, AR, RJL, JL, TR, FEJ, ER, CMK, MMvH, JJvdS, AEL, CC, TL, DRS, CS, MM, DM, AD, WHT, MAT, BIL, MW, LD, SEP, KLJ, ADP, DNF, RV, EM, JDR, ND, WBD, SFT, JRL recruited and phenotyped patients. HY, HS, AW, WC, CH, HK, BIL, SFT performed in vitro experiments. KP, HY, HS, AW, WC, CH, HK, HOH, ND, WBD, BL, SFT, JRL performed data analysis and statistics. KP, HY, SFT, JRL wrote the manuscript. All authors edited the manuscript.

Competing interests SFT is a consultant of Janssen Pharmaceuticals, Inc., Pfizer Inc., Boehringer Ingelheim Pharma GmbH \& Co. $\mathrm{KG}$, and co-founder of NeurOp Inc.

Provenance and peer review Not commissioned; externally peer reviewed.

Data sharing statement This study makes use of data generated by the DECIPHER community. A full list of centres who contributed to the generation of the data is available from and via email from decipher@sanger.ac.uk. 


\section{INTRODUCTION}

$\mathrm{N}$-methyl-D-aspartate receptors (NMDAR) are ligand-gated ion channels expressed throughout the brain mediating excitatory neurotransmission. Signalling via NMDAR plays an important role in brain development, learning, memory and other higher cognitive functions. NMDAR are di-heterotetramers or triheterotetramers composed of two glycinebindingGluN1(encodedby GRIN1)andtwo glutamate-binding GluN2 subunits (GRIN2A-D). ${ }^{1}$ Simultaneous binding of both agonists activates the NMDAR, which opens a cation-selective pore leading to an influx of $\mathrm{Ca}^{2+}$ and depolarisation. Compared with the ubiquitously expressed GluN1 subunit, the GluN2 subunits show specific spatiotemporal expression profiles throughout the central nervous system. ${ }^{2}$ GluN2B and GluN2D subunits are expressed prenatally, whereas expression of GluN2A and GluN2C significantly increases shortly after birth. Over time, postnatal expression of GluN2B becomes progressively restricted to the forebrain.

Pathogenic de novo variants in four genes encoding NMDAR subunits (GRIN1, GRIN2A, GRIN2B and GRIN2D) have been identified in patients with neurodevelopmental disorders comprising developmental delay (DD), intellectual disability (ID), autism spectrum disorders (ASD), epilepsy and epileptic encephalopathy, as well as movement disorders such as choreoathetosis or dystonia. ${ }^{3-13}$

To delineate the phenotypic spectrum of GRIN $2 B$ encephalopathy, we reviewed previously published and newly diagnosed patients with pathogenic/likely pathogenic de novo variants in GRIN2B. We evaluated the functional consequences of 16 variants in Xenopus laevis oocytes, investigated in vitro responses to memantine for six potential gain-of-function variants and aimed for translation of these results into personalised therapeutic approaches.

\section{MATERIALS AND METHODS}

\section{Patients}

We reviewed the clinical and genetic data of patients in whom GRIN2B de novo variants were detected within diagnostic or research settings focusing on neurodevelopmental disorders. Referring physicians provided detailed clinical information via a standardised clinical questionnaire. Molecular diagnostics were performed by targeted panel sequencing, ${ }^{14}$ whole exome sequencing (WES) or array comparative genomic hybridisation. All legal guardians provided informed written consent for genetic testing in accordance with the respective national ethics guidelines and with approval of the local ethics committees in the participating study centres.

\section{Variant classification}

Variants in GRIN2B (NM_000834.3) were determined to be pathogenic, likely pathogenic or of unknown significance according to established guidelines of the American College of Medical Genetics (ACMG) (tables 1 and 2). ${ }^{15}$ All variants classified as (likely) pathogenic constitute de novo variants. The database of the Exome Aggregation Consortium (ExAC) served as the control population. ${ }^{16}$ 


\section{GRIN2B physiology}

We used cDNA for wild-type (WT) human NMDA GluN1-1a (hereafter GluN1; NP_015566) and GluN2B subunits in pCI-neo (NP_000827.1). ${ }^{17}$ The mutant GluN2B constructs were generated by site-directed mutagenesis using the Quik-Change protocol (Stratagene). Synthesis and injection of cRNA into Xenopus laevis oocytes (Ecocyte Inc.) and two-electrode voltage-clamp current (TEVC) recordings were performed at $-40 \mathrm{mV}$ and $23^{\circ} \mathrm{C}$ (unless otherwise stated), as previously described. ${ }^{18}$ Recording electrodes were filled with $0.3 \mathrm{M} \mathrm{KCl}$ for voltage electrode and $3 \mathrm{M} \mathrm{KCl}$ for the current electrode. The recording solution contained (in mM) $90 \mathrm{NaCl}, 1 \mathrm{KCl}, 10 \mathrm{HEPES}, 0.5 \mathrm{BaCl}_{2}$ and 0.01 EDTA (pH 7.4). The concentration-response curves were fitted with the following equations:

$$
\text { Response }(\%)=100 /\left(1+\left(\mathrm{EC}_{50} /(\text { agonist })\right)^{n H}\right) \quad \text { Equation } 1
$$

$$
\text { Response }(\%)=(100-\text { minimum }) /\left(1+\left((\text { antagonist }) / \mathrm{IC}_{50}\right)^{n H}\right)+\text { minimum } \quad \text { Equation } 2
$$

where $n H$ is the Hill slope, $\mathrm{EC}_{50}$ is the concentration of the agonist that produces a halfmaximal effect, $\mathrm{IC}_{50}$ is the concentration of the antagonist that produces a half-maximal effect, and minimum is the degree of residual inhibition at a saturating concentration of the antagonist. The effects of co-application of increasing concentrations of memantine and maximally effective concentrations of glutamate $(100 \mu \mathrm{M})$ and glycine $(30 \mu \mathrm{M})$ on the response of NMDAR were determined using TEVC recordings from oocytes co-expressing GluN1 with the WT or the mutant GluN2B. The concentration-effect curves were recorded at a holding potential of $-40 \mathrm{mV}$ and fitted with equation 2 .

\section{Patient treatment}

Patients were offered memantine treatment after functional confirmation of a gain-offunction variant retaining memantine sensitivity in vitro. In four patients, oral memantine treatment was initiated aiming for doses of $0.5-0.6 \mathrm{mg} / \mathrm{kg}$ body weight per day referring to the dosage of a treatment trial in GRIN2A encephalopathy. ${ }^{19}$ Patients were neurologically assessed prior and during memantine treatment. Individual treatment trials were approved by the local ethics boards of the participating centres.

\section{RESULTS}

We evaluated 48 novel and all 43 previously published individuals with de novo GRIN2B variants. Overall, variants in 86 out of these 91 individuals were classified as pathogenic/ likely pathogenic. For 58 patients ( 39 novel and 19 published), detailed clinical data were available to comprehensively delineate the phenotypic spectrum of GRIN2B encephalopathy. The novel variant p.(Ser810Arg) was identified in monozygotic twin brothers with identical phenotype who were thus regarded as only one index case. 


\section{Phenotypic spectrum}

All patients carrying a (likely) pathogenic GRIN2B variant presented with DD, ID and/or ASD $(86 / 86 ; 100 \%$, table 1 , table 2, detailed phenotypic data in online supplementary table $3)$. The level of ID could be specified in 52 of 58 patients, with a majority displaying severe ID $(31 / 52 ; 60 \%)$, whereas smaller proportions had moderate $(13 / 52 ; 25 \%)$ or mild ID $(8 / 52$; $15 \%)$. Autistic features were seen in $28 \%$ of patients $(16 / 58)$. At the time of data ascertainment, about half of the patients have had seizures (30/58; 52\%), with a variable age of onset ranging from birth to 9 years and the frequency of seizures varying from multiple per day to a few seizures per year. Patients presented with generalised seizures $(18 / 30 ; 60 \%$, mostly tonic or tonic-clonic), focal seizures $(14 / 30 ; 47 \%)$ and/or epileptic spasms $(11 / 30$; $37 \%$ ). EEG patterns comprised hypsarrhythmia, focal, multifocal and/or generalised epileptiform activity. Follow-up data concerning seizure outcome were available for 22 patients, with one half becoming seizure-free $(11 / 22 ; 50 \%)$ and the other half remaining refractory to therapy. No obvious treatment strategy using conventional antiepileptic drugs (AED) was associated with a higher likelihood of seizure freedom. At least 31 patients displayed hypotonia $(31 / 58 ; 53 \%)$, which required tube feeding in five patients $(5 / 31 ; 16 \%)$. Spasticity was documented in 14 patients $(14 / 58 ; 24 \%)$. In addition, six patients presented with dystonic, dyskinetic or choreiform movement disorders $(6 / 58 ; 10 \%)$. Four patients $(4 / 58 ; 7 \%)$ showed signs of developmental regression, two of whom were temporary and one case had recurrent regression. Microcephaly was seen in multiple patients $(11 / 58 ; 19 \%)$ and cortical visual impairment (CVI) was reported in four $(4 / 58 ; 7 \%)$, three of whom also had a malformation of cortical development (MCD).

\section{Neuroimaging data}

Neuroimaging was performed in 44 of 58 patients: six patients $(6 / 44,14 \%)$ showed a consistent MCD intermediate between typical polymicrogyria (PMG) and the cortical appearance of tubulinopathies, consisting of mixed large and small gyri separated by shallow sulci, a smooth grey-white border and little infolding (figure 1). These patients also had hypoplastic corpus callosum of varying degrees, enlarged and mildly dysplastic basal ganglia, hippocampal dysplasia with thick leaves and open hilus as well as enlarged tecta (figure 1A, E and M). One patient had no septum pellucidum (figure 1C). Generalised cerebral volume loss, compatible with cerebral atrophy, was described in four additional patients $(4 / 44 ; 9 \%)$.

\section{Genetic spectrum}

The 86 (likely) pathogenic variants in GRIN2B comprise 52 distinct missense variants. Variants cluster within or in very close proximity to the ligand-binding domains S1 and S2, as well as transmembrane domains M1-M4 (figure 2A, table 1). The only variant escaping this clustering pattern is p.(Ile150Val) in the amino-terminal domain (ATD). Although most variants were unique, five variants occurred multiple times: p.(Arg540His), p.(Gly689Ser), p.(Arg696His), p.(Ile751Thr) and p.(Gly820Ala). The 21 distinct pathogenic variants presumably leading to truncation/haploinsufficiency comprised nonsense and frameshift variants $(\mathrm{n}=11)$, splice site variants $(\mathrm{n}=3)$, chromosomal rearrangements $(\mathrm{n}=3)$ as well as gross deletions encompassing only GRIN2B (n=4) (figure $2 \mathrm{~B}$, table 2 ). According to the 
ACMG criteria, five de novo variants were classified as variants of unknown significance (see online supplement 2). ${ }^{15}$

\section{Frequency of GRIN2B encephalopathy}

Several of our collaborators (RSM, DS, CS and SB) performed different diagnostic panel sequencing approaches in 3136 independent epilepsy patients revealing seven (likely) pathogenic GRIN $2 B$ variants and a diagnostic frequency of $0.22 \%$. Three diagnostic WES trio cohorts reported 8051 patients with neurodevelopmental disorders (defined as human phenotype ontology terms (1) abnormality of the nervous system, (2) multiple congenital anomalies, (3) seizures or (4) ASD. ${ }^{20-22}$ Overall, 15 pathogenic/likely pathogenic GRIN2B variants (14 missense, 1 frameshift) were identified, equalling a similar frequency of $0.19 \%$. Expanding the data of the Deciphering Developmental Disorders Study, ${ }^{23} 14$ de novo missense variants in GRIN2B are significantly enriched ( $\mathrm{p}$ value $2 \times 10^{-17}$ ) in a combined cohort of WES trio data $(\mathrm{n}=8051)$ of patients with neurodevelopmental disorders (see online supplement 3). Among 209 independent individuals with PMG, we identified two patients with de novo GRIN2B variants.

\section{Functional investigation}

Seven of 17 variants evaluated showed small apparent currents (less than $15 \mathrm{nA}$ for $1000 \mu \mathrm{M}$ glutamate and $100 \mu \mathrm{M}$ glycine) (see online supplementary table 1). Because it was unclear whether these small currents were agonist evoked, the properties of these variants could not be studied further. We assessed the pharmacological properties of NMDAR containing the remaining 10 GluN2B mutants. Three variants (p.(Ser541Arg), p.(Val558Ile), and p. (Ile655Phe) increased glutamate $\mathrm{EC}_{50}$ values (ie, decreased glutamate potency) by 6.7 -fold, 2.8-fold and 3.7-fold (table 3), indicating that higher concentrations of glutamate are needed to activate these receptors. The variant $\mathrm{p}$.(Ser541 Arg) increased glycine $\mathrm{EC}_{50}$ values by 2.9fold compared with WT receptors. Three variants (p.(Ser810Arg), p.(Met818Thr), and p. $(\mathrm{Al}-\mathrm{a} 819 \mathrm{Thr})$ ) decreased both the glutamate and glycine $\mathrm{EC}_{50}$ values (ie, increased glutamate and glycine potency) (table 3), allowing these mutant receptors to be activated by lower concentration of agonists, suggesting a potential gain-of-function, provided trafficking and other features of receptor function are unchanged.

Voltage-dependent inhibition by extracellular $\mathrm{Mg}^{2+}$ and negative modulation by extracellular protons are two important features of NMDAR function. The voltage-dependent potency of $\mathrm{Mg}^{2+}$ inhibition showed that p.(Gly611Val) and p.(Ile655Phe) increased the $\mathrm{Mg}^{2+} \mathrm{IC}_{50}$ value from $25 \mu \mathrm{M}$ for WT NMDAR to over $1000 \mu \mathrm{M}$ and $220 \mu \mathrm{M}$ for NMDAR containing GluN2B-Gly611Val and GluN2B-Ile655Phe, respectively ( $-60 \mathrm{mV}$ holding potential; $\mathrm{p}<0.05$, one-way analysis of variance) (table 3 ). Proton sensitivity was evaluated by comparing the current amplitude at two different extracellular $\mathrm{pH}$ values (6.8 vs. 7.6). Four mutant GluN2B subunits (p.(Ile655Phe), p.(Ser810Arg), p.(Met818Thr) and p.(Ala819Thr)) show significantly larger current response at $\mathrm{pH} 6.8$ compared with $\mathrm{pH} 7.6$ than WT receptors (table 3), suggesting that these variants significantly reduce tonic proton inhibition. This could result in more current flowing through the channel when the receptor is bound by agonists. Taken together, these data suggest that three variants (p.(Ser810Arg), p.

(Met818Thr) and p.(Ala819Thr)) are likely overactive under resting conditions as a result of 
both the increased activation at low concentrations of agonists, reduced voltage-dependent $\mathrm{Mg}^{2+}$ block and reduced proton inhibition. The combination of these effects could potentially contribute to hyperexcitability and thus to patients' epileptic phenotype. Further data are needed to determine how receptors with mixed functional changes (decreased agonist potency, decreased regulation by $\mathrm{Mg}^{2+}$ or protons) will alter, for example, charge transfer during synaptic transmission.

\section{Evaluation of NMDAR antagonist memantine}

The Food and Drug Administration-approved NMDAR antagonist memantine ${ }^{24}$ has been suggested to have anticonvulsant effects in some epilepsy animal models ${ }^{25}$ and was previously used off-label to effectively treat one patient with a gain-of-function GluN2A variant (p.(Leu812Met)). ${ }^{19}$ Thus, we evaluated its ability to inhibit six potential gain-offunction GluN2B variants (p.(Gly611Val), p.(Asn615Ile), p.(Val618Gly), p.(Ser810Arg), p. (Met818Thr) and p.(Ala819Thr) $)^{9}$ (see online supplementary figure 1 and supplementary table 2). The data indicated GluN2B-Gly611Val and GluN2B-Asn615Ile decreased memantine $\mathrm{IC}_{50}$ by 1.7 -fold and 3 -fold, respectively (ie, increased potency; $1.0 \mu \mathrm{M}$ for $\mathrm{p}$. (Gly611Val) and $0.44 \mu \mathrm{M}$ for p.(Asn615Il)e compared with $1.7 \mu \mathrm{M}$ of WT). The other four variants (p.(Val618Gly), p.(Ser810Arg), p.(Met818Thr) and p.(Ala819Thr)) increased the $\mathrm{IC}_{50}$ values (ie, decreased potency) compared with WT (see online supplementary figure 1 and supplementary table 2), suggesting that memantine can reduce NMDAR hyperactivity caused by these variants, although several mutants showed a reduced potency compared with WT receptors.

\section{Targeted treatment with memantine}

In four out of these six patients, we added memantine to the AED regimen (p.(Gly611Val), p.(Asn615Ile), p.(Val618Gly) and p.(Met818Thr)) (see online supplement 1). Parents and physicians initially observed beneficial effects such as improvements in awareness, behaviour and sleep. However, there were no changes in seizure frequencies and none of the potential benefits could be sufficiently objectivised. Long-term follow-up data were available in only one patient (p.(Val618Gly)) and did not suggest significant improvement.

\section{DISCUSSION}

We present the largest series of patients with (likely) pathogenic GRIN2B variants and provide a comprehensive review of the different aspects of GRIN2B encephalopathy. We strictly applied the ACMG criteria for variant classification to lessen the impact of potential biases caused by the heterogeneous collection of patients.

\section{Phenotypic spectrum}

In agreement with the known GRIN2B-associated features, our data confirm that all patients had DD and a majority developed severe ID, with autistic features in a quarter of patients. Half of the patients developed seizures with a broad heterogeneity with respect to age of onset, seizure semiology, EEG features and outcome. Expanding our previous observation, $37 \%$ of patients presented with epileptic spasms. ${ }^{9}$ Less frequent findings of GRIN2B encephalopathy include generalised cerebral volume loss, CVI, hyperkinetic movement 
disorders (dystonia, dyskinesia, chorea) and developmental regression. These features have been repeatedly observed in other GRIN-associated encephalopathies, ${ }^{451012192627}$ suggesting a shared phenotypic spectrum, with differences likely reflecting variant class, location and effect in the various NMDAR subunits. However, we did not observe EEG patterns of continuous spikes and waves during sleep or centrotemporal spikes in our GRIN2B cohort, which appears to reflect a milder end of the GRIN spectrum that is so far predominantly associated with GRIN $2 A .{ }^{28}$ As systematic genetic testing is more likely performed in patients with severe early-onset disorders, the mentioned frequencies of, for example, severe ID and epilepsy in GRIN2B encephalopathy are probably overestimated due to ascertainment bias.

\section{Malformation of cortical development}

Six patients presented with a consistent MCD intermediate between typical PMG and tubulinopathies. This has also been referred to as tubulinopathy-related dysgyria. ${ }^{29}$ Whereas tubulinopathies are classified as disorders of neuronal migration leading to cortical dysgenesis, ${ }^{30} \mathrm{PMG}$ is considered to be due to postmigrational disruption of cortical development with fusion of cortical laminae. ${ }^{31}$ Knockdown of Grin $2 b$ in rat has been shown to disturb proper neuronal migration ${ }^{32}$ and glutamate has been implemented in its regulation. ${ }^{33}$ As GluN2B is predominantly expressed prenatally, disruption of neuronal migration seems to be the possible cause of GRIN2B-associated MCD. All six individuals had a very similar degree of severity and we did not observe less pronounced patterns of dysgyria in others. We can largely exclude the co-occurrence of, for example, known genetic tubulinopathies in all six cases, as individuals were screened by (trio)WES ( $\mathrm{n}=4$ ) or a panel targeting MCD genes (n=2). Other than in GRIN2B, we did not identify any other putatively causative variants in all six cases. Deficient ion channels are known to cause a plethora of human neurodevelopmental disorders, with the exception of abnormal cell migration.

Despite the observation of six patients with pathogenic $S C N 1 A$ variants who also had focal cortical dysplasia or bilateral periventricular nodular heterotopia, ${ }^{34}$ the identification of six unrelated individuals with (likely) pathogenic variants in GRIN2B and a consistent MCD expands the phenotypic spectrum and reveals novel phenotypic consequences of channelopathies.

\section{Genetic spectrum}

GRIN2B is a gene with a significantly reduced number of missense variants in controls, indicating a selective constraint. ${ }^{16}$ All (likely) pathogenic missense variants cluster within or in direct proximity to ligand-binding sites and transmembrane domains. These regions are largely spared by (likely) benign single nucleotide variants (SNV) in ExAC controls, suggesting that missense variants within these functionally important and conserved domains are only scarcely tolerated. ${ }^{3536}$ In contrast, the ATD and carboxy-terminal domain (CTD), as well as two small segments within S1 and M1, are markedly enriched for (likely) benign SNV in controls. The likely pathogenic missense variant p.(I-le150Val) escapes this clustering pattern, as it is located within a stretch of $\sim 300$ bp that contains very few missense variants within the ATD. It remains unclear whether or not this variant alters subunit assembly, ligand-binding or allosteric regulation by extracellular $\mathrm{Zn}^{2+.12}$ 
The ratio of expected versus observed numbers of truncating variants of 33.9:0 in controls and the probability of loss-of-function intolerant score of 1.00 suggest that GRIN2B haploinsufficiency is most likely not tolerated. ${ }^{16}$ We observed seven truncating variants in the CTD establishing a premature termination codon in the last exon and therefore likely escaping nonsense-mediated mRNA decay and possibly not significantly altering protein function ${ }^{1537}$ : two de novo truncating variants in patients with $\mathrm{ID}^{20},{ }^{20}$ one de novo frameshift variant in a healthy control individual ${ }^{38}$ and four frameshift variants reported in ExAC. The ExAC-annotated frameshift variant c.99dupC, p.(Ser34Gln $\left.f s^{*} 25\right)$ occurring in 27 controls conflicts with the hypothesis of haploinsufficiency. However, this variant is part of a homopolymer stretch of seven recurrent $\mathrm{C}$ nucleotides, raising the suspicion of a technical artefact despite having been described as pathogenic de novo variant via different sequencing approaches in an individual with ASD. ${ }^{39}$

\section{Genotype-phenotype correlations}

MCD-associated variants are located in the transmembrane domain M3 (p.(Ala636Val), p. (Ala639Val) and p.(Ile655Phe)), in the ligand-binding domain S2 (p.(Arg693Ser)) or within the linker domain connecting S2 and M4 (p.(Ser810Arg) and p.(Ser810Asn)). Both missense variants at position 810 (p.(Ser810Arg) and p. (Ser810Asn)) were associated with MCD, whereas position 636 also showed two different (likely) pathogenic missense variants, with only p.(Ala636Val) being seen in MCD. ${ }^{40}$ Thus, the specific functional mechanisms mediating MCD still remain to be elucidated. In contrast to our previous hypothesis, ${ }^{9}$ we did not find a significant correlation between variant class (missense vs truncation) and occurrence of seizures (Fisher's exact test, $\mathrm{p}=0.1187$ ). However, there was a significant correlation between variant class and intellectual outcome (mild-moderate vs severe ID) (Fisher's exact test, $\mathrm{p}=0.0079$ ), with truncation carriers tending to present with mild or moderate instead of severe ID.

\section{Functional investigation}

We evaluated several different aspects of receptor function, as it is possible that variants could have opposing effects on receptor activity (eg, Ile655Phe). We found that several other variants (Ser810Arg, Met818Thr, Ala819Thr) showed multiple differences in their properties that each enhanced NMDAR function, suggesting a potential gain-of-function of NMDAR assuming there is no change in the fraction of receptors that reach the cell surface or synapse. Such functional changes could lead to excito-toxic cell death, circuit rewiring, changes in neuronal migration or persistent increases in excitatory synaptic and non-synaptic drive through surface receptors. Thus there are multiple ways these variant receptors could contribute to clinical symptoms. Extensive functional analyses of rare variants in the GluN2B agonist binding domain recently showed the multifaceted and sometimes conflicting consequences that these variants can have on NMDAR activity. ${ }^{36}$

\section{Targeted treatment with memantine}

Initial subjective improvements in awareness, behaviour and sleep could not be sufficiently objectivised, and seizure frequencies showed no significant changes. In three cases, the missense variant led to significant loss of $\mathrm{Mg}^{2+}$ block engaging a different mechanism compared with the multiple means by which channel function was enhanced in a patient 
with p.(Leu812Met) in GRIN2A, which responded favourably to memantine treatment. ${ }^{19}$ In comparison, the variant of the fourth individual (p.(Met818Thr)) displayed similarities with respect to, for example, the increased glycine and glutamate potency of the NMDAR;

however this does not hold true for patients' treatment response to memantine. At present, it remains entirely unclear whether memantine is effective at all in this patient population and what factors (eg, variant location, mechanism of gain-of-function, patient age, memantine dose, differences in blood and brain concentrations) might influence memantine treatment response. Although some variants retain sensitivity to channel blockers like memantine in vitro, translating these potential benefits into patient care still remains elusive. Options for personalised therapy in GRIN2B encephalopathy still require more systematic and thorough evidence best through double-blinded prospective trials with a homogeneous patient population in terms of variant class.

\section{Summary}

Given the frequency of about $0.2 \%$ among individuals with neurodevelopmental disorders and/or childhood-onset epilepsy, GRIN2B encephalopathy appears to be a recurrent and distinct diagnosis. Our observations of novel features expand the phenotypic spectrum and suggest novel consequences of channelopathies resulting in disturbed neuronal migration. We found phenotypic similarities and a marked clustering of missense variants in ligandbinding and transmembrane domains paralleling other GRIN-associated disorders. Despite the limited conclusions regarding treatment with memantine in four patients with potential gain-of-function variants, the diverse functional consequences of (likely) pathogenic variants possibly enable future personalised therapeutic approaches in patients with GRIN2B encephalopathy.

\section{Supplementary Material}

Refer to Web version on PubMed Central for supplementary material.

\section{Authors}

Konrad Platzer ${ }^{1}$, Hongjie Yuan ${ }^{2,3}$, Hannah Schütz ${ }^{4}$, Alexander Winschel ${ }^{4}$, Wenjuan Chen $^{2}$, Chun Hu${ }^{2}$, Hirofumi Kusumoto ${ }^{2}$, Henrike O Heyne ${ }^{1}$, Katherine L Helbig ${ }^{5}$, Sha Tang ${ }^{5}$, Marcia C Willing ${ }^{6}$, Brad T Tinkle ${ }^{7}$, Darius J Adams ${ }^{8}$, Christel Depienne ${ }^{9,10,11,12}$, Boris Keren ${ }^{9,10}$, Cyril Mignot ${ }^{10}$, Eirik Frengen ${ }^{13}$, Petter Strømme ${ }^{14}$, Saskia Biskup ${ }^{15}$, Dennis Döcker ${ }^{15}$, Tim M Strom ${ }^{16}$, Heather C Mefford $^{17}$, Candace T Myers ${ }^{17}$, Alison M Muir ${ }^{17}$, Amy LaCroix ${ }^{17}$, Lynette Sadleir ${ }^{18}$, Ingrid $\mathrm{E}$ Scheffer ${ }^{19}$, Eva Brilstra ${ }^{20}$, Mieke $\mathrm{M}$ van Haelst ${ }^{20}$, Jasper $\mathrm{J}$ van der Smagt $^{20}$, Levinus A Bok ${ }^{21}$, Rikke S Møller ${ }^{22,23}$, Uffe B Jensen ${ }^{24}$, John J Millichap ${ }^{25}$, Anne T Berg ${ }^{25}$, Ethan M Goldberg ${ }^{26,27}$, Isabelle De Bie ${ }^{28}$, Stephanie Fox ${ }^{28}$, Philippe Major $^{29}$, Julie R Jones ${ }^{30}$, Elaine H Zackai ${ }^{31}$, Rami Abou Jamra ${ }^{1,32}$, Arndt Rolfs $^{32}$, Richard J Leventer ${ }^{33,34}$, John A Lawson ${ }^{35}$, Tony Roscioli ${ }^{36}$, Floor E Jansen $^{37}$, Emmanuelle Ranza ${ }^{38}$, Christian M Korff ${ }^{39}$, Anna-Elina Lehesjoki ${ }^{40,41}$, Carolina Courage ${ }^{40,41}$, Tarja Linnankivi ${ }^{42}$, Douglas R Smith ${ }^{43}$, Christine Stanley ${ }^{43}$, Mark Mintz ${ }^{44}$, Dianalee McKnight ${ }^{45}$, Amy Decker ${ }^{45}$, Wen-Hann Tan ${ }^{46}$, Mark A Tarnopolsky ${ }^{47}$, Lauren I Brady ${ }^{47}$, Markus Wolff ${ }^{48}$, Lutz Dondit ${ }^{49}$, Helio F Pedro ${ }^{50}$, 
Sarah E Parisotto ${ }^{50}$, Kelly L Jones ${ }^{51}$, Anup D Pate $\left.\right|^{52,53}$, David N Franz ${ }^{54}$, Rena Vanzo ${ }^{55}$, Elysa Marco ${ }^{56}$, Judith D Ranells ${ }^{57}$, Nataliya Di Donato ${ }^{58}$, William B Dobyns $^{59,60,61}$, Bodo Laube ${ }^{4}$, Stephen F Traynelis ${ }^{2,3}$, and Johannes R Lemke ${ }^{1}$

\section{Affiliations}

${ }^{1}$ Institute of Human Genetics, University of Leipzig Hospitals and Clinics, Leipzig, Germany ${ }^{2}$ Department of Pharmacology, Emory University School of Medicine, Rollins Research Center, Atlanta, Georgia, USA ${ }^{3}$ Center for Functional Evaluation of Rare Variants (CFERV), Emory University School of Medicine, Atlanta, Georgia, USA ${ }^{4}$ Department of Neurophysiology and Neurosensory Systems, Technical University Darmstadt, Darmstadt, Hessen, Germany ${ }^{5}$ Division of Clinical Genomics, Ambry Genetics, Aliso Viejo, California, USA ${ }^{6}$ Department of Pediatrics, Washington University in St. Louis School of Medicine, St. Louis, Missouri, USA ${ }^{7}$ Advocate Children's Hospital, Park Ridge, Illinois, USA ${ }^{8}$ Genetics and Metabolism, Goryeb Children's Hospital, Atlantic Health System, Morristown, New Jersey, USA 9 INSERM, U 1127, Sorbonne Universités, UPMC Université Paris 06, CNRS, UMR 7225 , Institut du cerveau et de la moelle épinière (ICM), Paris, France ${ }^{10}$ Département de Génétique, Centre de Référence des Déficiences Intellectuelles de Causes Rares, GRC UPMC "Déficiences Intellectuelles et Autisme", Hôpital de la Pitié-Salpêtrière, Paris, France ${ }^{11}$ UMR 7104/INSERM U964/Université de Strasbourg, Illkirch, France ${ }^{12}$ Laboratoire de cytogénétique, Hôpitaux Universitaires de Strasbourg, Strasbourg, France ${ }^{13}$ Department of Medical Genetics, Oslo University Hospitals and University of Oslo, Oslo, Norway ${ }^{14}$ Department of Pediatrics, Oslo University Hospitals and University of Oslo, Oslo, Norway ${ }^{15}$ Practice for Human Genetics and CeGaT GmbH, Tübingen, Germany ${ }^{16}$ Institute of Human Genetics, Helmholtz Zentrum München, German Research Center for Environmental Health, Neuherberg, Germany ${ }^{17}$ Department of Pediatrics, Division of Genetic Medicine, University of Washington, Seattle, Washington, USA ${ }^{18}$ Department of Paediatrics and Child Health, University of Otago, Wellington, New Zealand ${ }^{19}$ Department of Medicine, University of Melbourne, Austin Health and Royal Children's Hospital, Melbourne, Victoria, Australia ${ }^{20}$ Department of Genetics, Utrecht University Medical Center, Utrecht, The Netherlands ${ }^{21}$ Department of Paediatrics, Màxima Medical Centre, Veldhoven, The Netherlands ${ }^{22}$ The Danish Epilepsy Centre Filadelfia, Dianalund, Denmark ${ }^{23}$ Institute for Regional Health Services, University of Southern Denmark, Odense, Denmark ${ }^{24}$ Department of Clinical Genetics, Aarhus University Hospital, Aarhus, Denmark ${ }^{25}$ Departments of Pediatrics, Epilepsy Center and Division of Neurology Ann \& Robert H. Lurie Children's Hospital of Chicago, Northwestern University Feinberg School of Medicine, Chicago, Illinois, USA ${ }^{26}$ Division of Neurology, The Children's Hospital of Philadelphia, University of Pennsylvania, Philadelphia, Pennsylvania, USA ${ }^{27}$ Department of Neurology, Perelman School of Medicine, University of Pennsylvania, Philadelphia, Pennsylvania, USA ${ }^{28}$ Department of Medical Genetics, Montreal Children's Hospital, McGill University Health Center, Montreal, Canada ${ }^{29}$ Department of Neurological Sciences, Université de Montréal, CHU Ste-Justine, Montreal, Canada ${ }^{30}$ Greenwood Genetic Center, Greenwood, South Carolina, USA 
${ }^{31}$ Department of Pediatrics, Children's Hospital of Philadelphia, Philadelphia, Pennsylvania, USA ${ }^{32}$ Centogene AG, Rostock, Germany ${ }^{33}$ Department of Neurology, Royal Children's Hospital, Melbourne, Victoria, Australia ${ }^{34}$ Murdoch Childrens Research Institute and Department of Pediatrics, University of Melbourne, Melbourne, Victoria, Australia ${ }^{35}$ Department of Neurology, Sydney Children's Hospital, Sydney, New South Wales, Australia ${ }^{36}$ Genome.One, Sydney, New South Wales, Australia ${ }^{37}$ Department of Child Neurology, Brain Center Rudolf Magnus, University Medical Center, Utrecht, The Netherlands ${ }^{38}$ Service of Genetic Medicine, University Hospitals of Geneva, Geneva, Switzerland ${ }^{39}$ Department of Child and Adolescent, Neurology Unit, University Hospitals of Geneva, Geneva, Switzerland ${ }^{40}$ The Folkhälsan Institute of Genetics, University of Helsinki, Helsinki, Finland ${ }^{41}$ Research Programs Unit, Molecular Neurology and Neuroscience Center, University of Helsinki, Helsinki, Finland ${ }^{42}$ Department of Pediatric Neurology, Children's Hospital, University of Helsinki and Helsinki University Hospital, Helsinki, Finland ${ }^{43}$ Courtagen Life Sciences, Woburn, Massachusetts, USA ${ }^{44}$ The Center for Neurological and Neurodevelopmental Health and the Clinical Research Center of New Jersey, Voorhees, New Jersey, USA ${ }^{45}$ GeneDx, Gaithersburg, Maryland, USA ${ }^{46}$ Division of Genetics and Genomics, Boston Children's Hospital, Boston, Massachusetts, USA ${ }^{47}$ Department of Pediatrics, McMaster University Children's Hospital, Hamilton, Ontario, Canada ${ }^{48}$ Department of Pediatric Neurology and Developmental Medicine, University Children's Hospital, Tubingen, Germany ${ }^{49}$ Department of Pediatric Neurology and Center for Developmental Medicine, Olgahospital Stuttgart, Stuttgart, Germany ${ }^{50}$ Hackensack University Medical Center, Hackensack, New Jersey, USA ${ }^{51}$ Department of Pediatrics, Division of Medical Genetics, University of Mississippi Medical Center, Jackson, Mississippi, USA ${ }^{52}$ Nationwide Children's Hospital, Columbus, Ohio, USA ${ }^{53}$ The Ohio State University College of Medicine, Columbus, Ohio, USA ${ }^{54}$ Department of Neurology, Cincinnati Children's Hospital Medical Center, Cincinnati, Ohio, USA ${ }^{55}$ Lineagen, Inc., Salt Lake City, Utah, USA ${ }^{56}$ Department of Neurology, University of San Francisco School of Medicine, San Francisco, California, USA ${ }^{57}$ Department of Pediatrics, University of South Florida, Tampa, Florida, USA ${ }^{58}$ Institute for Clinical Genetics, Carl Gustav Carus Faculty of Medicine, TU Dresden, Dresden, Germany ${ }^{59}$ Center for Integrative Brain Research, Seattle Children's Research Institute, Seattle, Washington, USA ${ }^{60}$ Department of Pediatrics, University of Washington, Seattle, Washington, USA ${ }^{61}$ Department of Neurology, University of Washington, Seattle, Washington, USA

\section{Acknowledgments}

We thank the patients and their families for their participation and support of this study. We thank Lisa Ewans, Michael F Buckley, Asbjørn Holmgren and Doriana Misceo for technical support.

Funding

Funding for the project was provided by the Eunice Kennedy Shriver National Institute of Child Health \& Human Development (R01HD082373 to HY), by the National Center for Advancing Translational Sciences of the National 
Institutes of Health under Award Number UL1TR000454 (to HY), and by the National Institute of Neurological Disorders and Stroke (NS036654, R01NS065371 and R24NS092989 to SFT). The content is solely the responsibility of the authors and does not necessarily represent the official views of the funding agencies.Additional funding was received from the Australian NHMRC (512123 to TR), NIH NINDS training grant (K12 NS049453 to EMG), Cure Kids NZ to LS and the SNSF Early Postdoc fellowship (P2SKP3_164945 to CC). Funding for the DECIPHER project was provided by the Wellcome Trust.

\section{References}

1. Traynelis SF, Wollmuth LP, McBain CJ, Menniti FS, Vance KM, Ogden KK, Hansen KB, Yuan H, Myers SJ, Dingledine R. Glutamate receptor ion channels: structure, regulation, and function. Pharmacol Rev. 2010; 62:405-96. [PubMed: 20716669]

2. Paoletti P, Bellone C, Zhou Q. NMDA receptor subunit diversity: impact on receptor properties, synaptic plasticity and disease. Nat Rev Neurosci. 2013; 14:383-400. [PubMed: 23686171]

3. Burnashev N, Szepetowski P. NMDA receptor subunit mutations in neurodevelopmental disorders. Curr Opin Pharmacol. 2015; 20:73-82. [PubMed: 25498981]

4. Endele S, Rosenberger G, Geider K, Popp B, Tamer C, Stefanova I, Milh M, Kortüm F, Fritsch A, Pientka FK, Hellenbroich Y, Kalscheuer VM, Kohlhase J, Moog U, Rappold G, Rauch A, Ropers HH, von Spiczak S, Tönnies H, Villeneuve N, Villard L, Zabel B, Zenker M, Laube B, Reis A, Wieczorek D, Van Maldergem L, Kutsche K. Mutations in GRIN2A and GRIN2B encoding regulatory subunits of NMDA receptors cause variable neurodevelopmental phenotypes. Nat Genet. 2010; 42:1021-6. [PubMed: 20890276]

5. Hamdan FF, Gauthier J, Araki Y, Lin DT, Yoshizawa Y, Higashi K, Park AR, Spiegelman D, Dobrzeniecka S, Piton A, Tomitori H, Daoud H, Massicotte C, Henrion E, Diallo O, Shekarabi M, Marineau C, Shevell M, Maranda B, Mitchell G, Nadeau A, D’Anjou G, Vanasse M, Srour M, Lafrenière RG, Drapeau P, Lacaille JC, Kim E, Lee JR, Igarashi K, Huganir RL, Rouleau GA, Michaud JL. S2D Group. Excess of de novo deleterious mutations in genes associated with glutamatergic systems in nonsyndromic intellectual disability. Am J Hum Genet. 2011; 88:306-16. [PubMed: 21376300]

6. Lemke JR, Lal D, Reinthaler EM, Steiner I, Nothnagel M, Alber M, Geider K, Laube B, Schwake M, Finsterwalder K, Franke A, Schilhabel M, Jähn JA, Muhle H, Boor R, Van Paesschen W, Caraballo R, Fejerman N, Weckhuysen S, De Jonghe P, Larsen J, Møller RS, Hjalgrim H, Addis L, Tang S, Hughes E, Pal DK, Veri K, Vaher U, Talvik T, Dimova P, Guerrero López R, Serratosa JM, Linnankivi T, Lehesjoki AE, Ruf S, Wolff M, Buerki S, Wohlrab G, Kroell J, Datta AN, Fiedler B, Kurlemann G, Kluger G, Hahn A, Haberlandt DE, Kutzer C, Sperner J, Becker F, Weber YG, Feucht M, Steinböck H, Neophythou B, Ronen GM, Gruber-Sedlmayr U, Geldner J, Harvey RJ, Hoffmann P, Herms S, Altmüller J, Toliat MR, Thiele H, Nürnberg P, Wilhelm C, Stephani U, Helbig I, Lerche H, Zimprich F, Neubauer BA, Biskup S, von Spiczak S, de JP, von SS. Mutations in GRIN2A cause idiopathic focal epilepsy with rolandic spikes. Nat Genet. 2013; 45:1067-72. [PubMed: 23933819]

7. Carvill GL, Regan BM, Yendle SC, O’Roak BJ, Lozovaya N, Bruneau N, Burnashev N, Khan A, Cook J, Geraghty E, Sadleir LG, Turner SJ, Tsai MH, Webster R, Ouvrier R, Damiano JA, Berkovic SF, Shendure J, Hildebrand MS, Szepetowski P, Scheffer IE, Mefford HC. GRIN2A mutations cause epilepsy-aphasia spectrum disorders. Nat Genet. 2013; 45:1073-6. [PubMed: 23933818]

8. Lesca G, Rudolf G, Bruneau N, Lozovaya N, Labalme A, Boutry-Kryza N, Salmi M, Tsintsadze T, Addis L, Motte J, Wright S, Tsintsadze V, Michel A, Doummar D, Lascelles K, Strug L, Waters P, de Bellescize J, Vrielynck P, de Saint Martin A, Ville D, Ryvlin P, Arzimanoglou A, Hirsch E, Vincent A, Pal D, Burnashev N, Sanlaville D, Szepetowski P. GRIN2A mutations in acquired epileptic aphasia and related childhood focal epilepsies and encephalopathies with speech and language dysfunction. Nat Genet. 2013; 45:1061-6. [PubMed: 23933820]

9. Lemke JR, Hendrickx R, Geider K, Laube B, Schwake M, Harvey RJ, James VM, Pepler A, Steiner I, Hörtnagel K, Neidhardt J, Ruf S, Wolff M, Bartholdi D, Caraballo R, Platzer K, Suls A, De Jonghe P, Biskup S, Weckhuysen S. GRIN2B mutations in west syndrome and intellectual disability with focal epilepsy. Ann Neurol. 2014; 75:147-54. [PubMed: 24272827]

10. Lemke JR, Geider K, Helbig KL, Heyne HO, Schütz H, Hentschel J, Courage C, Depienne C, Nava C, Heron D, Møller RS, Hjalgrim H, Lal D, Neubauer BA, Nürnberg P, Thiele H, Kurlemann G, 
Arnold GL, Bhambhani V, Bartholdi D, Pedurupillay CR, Misceo D, Frengen E, Strømme P, Dlugos DJ, Doherty ES, Bijlsma EK, Ruivenkamp CA, Hoffer MJ, Goldstein A, Rajan DS, Narayanan V, Ramsey K, Belnap N, Schrauwen I, Richholt R, Koeleman BP, Sa J, Mendonça C, de Kovel CG, Weckhuysen S, Hardies K, De Jonghe P, De Meirleir L, Milh M, Badens C, Lebrun M, Busa T, Francannet C, Piton A, Riesch E, Biskup S, Vogt H, Dorn T, Helbig I, Michaud JL, Laube B, Syrbe S. Delineating the GRIN1 phenotypic spectrum: a distinct genetic NMDA receptor encephalopathy. Neurology. 2016:86.

11. Yuan H, Low CM, Moody OA, Jenkins A, Traynelis SF. Ionotropic GABA and glutamate receptor mutations and human neurologic diseases. Mol Pharmacol. 2015; 88:203-17. [PubMed: 25904555]

12. Li D, Yuan H, Ortiz-Gonzalez XR, Marsh ED, Tian L, McCormick EM, Kosobucki GJ, Chen W, Schulien AJ, Chiavacci R, Tankovic A, Naase C, Brueckner F, von Stülpnagel-Steinbeis C, Hu C, Kusumoto H, Hedrich UB, Elsen G, Hörtnagel K, Aizenman E, Lemke JR, Hakonarson H, Traynelis SF, Falk MJ. GRIN2D recurrent de novo dominant mutation causes a severe epileptic encephalopathy treatable with NMDA receptor channel blockers. Am J Hum Genet. 2016; 99:80216. [PubMed: 27616483]

13. Hu C, Chen W, Myers SJ, Yuan H, Traynelis SF. Human GRIN2B variants in neurodevelopmental disorders. J Pharmacol Sci. 2016; 132:115-21. [PubMed: 27818011]

14. Lemke JR, Riesch E, Scheurenbrand T, Schubach M, Wilhelm C, Steiner I, Hansen J, Courage C, Gallati S, Bürki S, Strozzi S, Simonetti BG, Grunt S, Steinlin M, Alber M, Wolff M, Klopstock T, Prott EC, Lorenz R, Spaich C, Rona S, Lakshminarasimhan M, Kröll J, Dorn T, Krämer G, Synofzik M, Becker F, Weber YG, Lerche H, Böhm D, Biskup S. Targeted next generation sequencing as a diagnostic tool in epileptic disorders. Epilepsia. 2012; 53:1387-98. [PubMed: 22612257]

15. Richards S, Aziz N, Bale S, Bick D, Das S, Gastier-Foster J, Grody WW, Hegde M, Lyon E, Spector E, Voelkerding K, Rehm HL. ACMG Laboratory Quality Assurance Committee. Standards and guidelines for the interpretation of sequence variants: a joint consensus recommendation of the American College of Medical Genetics and Genomics and the Association for Molecular Pathology. Genet Med. 2015; 17:405-23. [PubMed: 25741868]

16. Lek M, Karczewski KJ, Minikel EV, Samocha KE, Banks E, Fennell T, O’Donnell-Luria AH, Ware JS, Hill AJ, Cummings BB, Tukiainen T, Birnbaum DP, Kosmicki JA, Duncan LE, Estrada K, Zhao F, Zou J, Pierce-Hoffman E, Berghout J, Cooper DN, Deflaux N, DePristo M, Do R, Flannick J, Fromer M, Gauthier L, Goldstein J, Gupta N, Howrigan D, Kiezun A, Kurki MI, Moonshine AL, Natarajan P, Orozco L, Peloso GM, Poplin R, Rivas MA, Ruano-Rubio V, Rose SA, Ruderfer DM, Shakir K, Stenson PD, Stevens C, Thomas BP, Tiao G, Tusie-Luna MT, Weisburd B, Won HH, Yu D, Altshuler DM, Ardissino D, Boehnke M, Danesh J, Donnelly S, Elosua R, Florez JC, Gabriel SB, Getz G, Glatt SJ, Hultman CM, Kathiresan S, Laakso M, McCarroll S, McCarthy MI, McGovern D, McPherson R, Neale BM, Palotie A, Purcell SM, Saleheen D, Scharf JM, Sklar P, Sullivan PF, Tuomilehto J, Tsuang MT, Watkins HC, Wilson JG, Daly MJ, MacArthur DG. Exome Aggregation Consortium. Analysis of protein-coding genetic variation in 60,706 humans. Nature. 2016; 536:285-91. [PubMed: 27535533]

17. Hedegaard M, Hansen KB, Andersen KT, Bräuner-Osborne H, Traynelis SF. Molecular pharmacology of human NMDA receptors. Neurochem Int. 2012; 61:601-9. [PubMed: 22197913]

18. Hansen KB, Tajima N, Risgaard R, Perszyk RE, Jørgensen L, Vance KM, Ogden KK, Clausen RP, Furukawa H, Traynelis SF. Structural determinants of agonist efficacy at the glutamate binding site of N-methyl-D-aspartate receptors. Mol Pharmacol. 2013; 84:114-27. [PubMed: 23625947]

19. Pierson TM, Yuan H, Marsh ED, Fuentes-Fajardo K, Adams DR, Markello T, Golas G, Simeonov DR, Holloman C, Tankovic A, Karamchandani MM, Schreiber JM, Mullikin JC, Tifft CJ, Toro C, Boerkoel CF, Traynelis SF, Gahl WA. PhD for the NISC Comparative Sequencing Program. GRIN2A mutation and early-onset epileptic encephalopathy: personalized therapy with memantine. Ann Clin Transl Neurol. 2014; 1:190-8. [PubMed: 24839611]

20. Retterer K, Juusola J, Cho MT, Vitazka P, Millan F, Gibellini F, Vertino-Bell A, Smaoui N, Neidich J, Monaghan KG, McKnight D, Bai R, Suchy S, Friedman B, Tahiliani J, Pineda-Alvarez D, Richard G, Brandt T, Haverfield E, Chung WK, Bale S. Clinical application of whole-exome sequencing across clinical indications. Genet Med. 2016:18. 
21. Helbig KL, Farwell Hagman KD, Shinde DN, Mroske C, Powis Z, Li S, Tang S, Helbig I. Diagnostic exome sequencing provides a molecular diagnosis for a significant proportion of patients with epilepsy. Genet Med. 2016; 18:898-905. [PubMed: 26795593]

22. Trujillano D, Bertoli-Avella AM, Kumar Kandaswamy K, Weiss ME, Köster J, Marais A, Paknia O, Schröder R, Garcia-Aznar JM, Werber M, Brandau O, Calvo Del Castillo M, Baldi C, Wessel K, Kishore S, Nahavandi N, Eyaid W, Al Rifai MT, Al-Rumayyan A, Al-Twaijri W, Alothaim A, Alhashem A, Al-Sannaa N, Al-Balwi M, Alfadhel M, Rolfs A, Abou Jamra R. Clinical exome sequencing: results from 2819 samples reflecting 1000 families. Eur J Hum Genet. 2017:25.

23. Deciphering Developmental Disorders Study. Prevalence and architecture of de novo mutations in developmental disorders. Nature. 2017; 542:433-8. [PubMed: 28135719]

24. Lipton SA. Paradigm shift in NMDA receptor antagonist drug development: molecular mechanism of uncompetitive inhibition by memantine in the treatment of Alzheimer's disease and other neurologic disorders. J Alzheimers Dis. 2004; 6(Suppl):S61-74. [PubMed: 15665416]

25. Ghasemi M, Schachter SC. The NMDA receptor complex as a therapeutic target in epilepsy: a review. Epilepsy Behav. 2011; 22:617-40. [PubMed: 22056342]

26. Hamdan FF, Srour M, Capo-Chichi JM, Daoud H, Nassif C, Patry L, Massicotte C, Ambalavanan A, Spiegelman D, Diallo O, Henrion E, Dionne-Laporte A, Fougerat A, Pshezhetsky AV,

Venkateswaran S, Rouleau GA, Michaud JL. De novo mutations in moderate or severe intellectual disability. PLoS Genet. 2014; 10:e1004772. [PubMed: 25356899]

27. Ohba C, Shiina M, Tohyama J, Haginoya K, Lerman-Sagie T, Okamoto N, Blumkin L, Lev D, Mukaida S, Nozaki F, Uematsu M, Onuma A, Kodera H, Nakashima M, Tsurusaki Y, Miyake N, Tanaka F, Kato M, Ogata K, Saitsu H, Matsumoto N. GRIN1 mutations cause encephalopathy with infantile-onset epilepsy, and hyperkinetic and stereotyped movement disorders. Epilepsia. 2015; 56:841-8. [PubMed: 25864721]

28. Myers, KA., Scheffer, IE. GRIN2A-related speech disorders and epilepsy. In: Pagon, RA.Adam, MP., Ardinger, HH., editors. Gene Reviews (R). Seattle, WA: 1993.

29. Oegema R, Cushion TD, Phelps IG, Chung SK, Dempsey JC, Collins S, Mullins JG, Dudding T, Gill H, Green AJ, Dobyns WB, Ishak GE, Rees MI, Doherty D. Recognizable cerebellar dysplasia associated with mutations in multiple tubulin genes. Hum Mol Genet. 2015; 24:5313-25. [PubMed: 26130693]

30. Barkovich AJ, Dobyns WB, Guerrini R. Malformations of cortical development and epilepsy. Cold Spring Harb Perspect Med. 2015; 5:a022392. [PubMed: 25934463]

31. Judkins AR, Martinez D, Ferreira P, Dobyns WB, Golden JA. Polymicrogyria includes fusion of the molecular layer and decreased neuronal populations but normal cortical laminar organization. J Neuropathol Exp Neurol. 2011; 70:438-43. [PubMed: 21572338]

32. Jiang H, Jiang W, Zou J, Wang B, Yu M, Pan Y, Lin Y, Mao Y, Wang Y. The GluN2B subunit of Nmethy-D-asparate receptor regulates the radial migration of cortical neurons in vivo. Brain Res. 2015; 1610:20-32. [PubMed: 25838242]

33. Evsyukova I, Plestant C, Anton ES. Integrative mechanisms of oriented neuronal migration in the developing brain. Annu Rev Cell Dev Biol. 2013; 29:299-353. [PubMed: 23937349]

34. Barba C, Parrini E, Coras R, Galuppi A, Craiu D, Kluger G, Parmeggiani A, Pieper T, SchmittMechelke T, Striano P, Giordano F, Blumcke I, Guerrini R. Co-occurring malformations of cortical development and SCN1A gene mutations. Epilepsia. 2014; 55:1009-19. [PubMed: 24902755]

35. Ogden KK, Chen W, Swanger SA, McDaniel MJ, Fan LZ, Hu C, Tankovic A, Kusumoto H, Kosobucki GJ, Schulien AJ, Su Z, Pecha J, Bhattacharya S, Petrovski S, Cohen AE, Aizenman E, Traynelis SF, Yuan H. Molecular mechanism of disease-associated mutations in the Pre-M1 Helix of NMDA receptors and potential rescue pharmacology. PLoS Genet. 2017; 13:e1006536. [PubMed: 28095420]

36. Swanger SA, Chen W, Wells G, Burger PB, Tankovic A, Bhattacharya S, Strong KL, Hu C, Kusumoto H, Zhang J, Adams DR, Millichap JJ, Petrovski S, Traynelis SF, Yuan H. Mechanistic insight into NMDA receptor dysregulation by rare variants in the GluN2A and GluN2B agonist binding domains. Am J Hum Genet. 2016; 99:1261-80. [PubMed: 27839871]

37. Popp MW, Maquat LE. Organizing principles of mammalian nonsense-mediated mRNA decay. Annu Rev Genet. 2013; 47:139-65. [PubMed: 24274751] 
38. Rauch A, Wieczorek D, Graf E, Wieland T, Endele S, Schwarzmayr T, Albrecht B, Bartholdi D, Beygo J, Di Donato N, Dufke A, Cremer K, Hempel M, Horn D, Hoyer J, Joset P, Röpke A, Moog U, Riess A, Thiel CT, Tzschach A, Wiesener A, Wohlleber E, Zweier C, Ekici AB, Zink AM, Rump A, Meisinger C, Grallert H, Sticht H, Schenck A, Engels H, Rappold G, Schröck E, Wieacker P, Riess O, Meitinger T, Reis A, Strom TM. Range of genetic mutations associated with severe non-syndromic sporadic intellectual disability: an exome sequencing study. Lancet. 2012; 380:1674-82. [PubMed: 23020937]

39. O’Roak BJ, Vives L, Fu W, Egertson JD, Stanaway IB, Phelps IG, Carvill G, Kumar A, Lee C, Ankenman K, Munson J, Hiatt JB, Turner EH, Levy R, O’Day DR, Krumm N, Coe BP, Martin BK, Borenstein E, Nickerson DA, Mefford HC, Doherty D, Akey JM, Bernier R, Eichler EE, Shendure J. Multiplex targeted sequencing identifies recurrently mutated genes in autism spectrum disorders. Science. 2012; 338:1619-22. [PubMed: 23160955]

40. Freunscht I, Popp B, Blank R, Endele S, Moog U, Petri H, Prott EC, Reis A, Rübo J, Zabel B, Zenker M, Hebebrand J, Wieczorek D. Behavioral phenotype in five individuals with de novo mutations within the GRIN2B gene. Behav Brain Funct. 2013; 9:20. [PubMed: 23718928]

41. Adams DR, Yuan H, Holyoak T, Arajs KH, Hakimi P, Markello TC, Wolfe LA, Vilboux T, Burton BK, Fajardo KF, Grahame G, Holloman C, Sincan M, Smith AC, Wells GA, Huang Y, Vega H, Snyder JP, Golas GA, Tifft CJ, Boerkoel CF, Hanson RW, Traynelis SF, Kerr DS, Gahl WA. Three rare diseases in one sib pair: rai1, PCK1, GRIN2B mutations associated with Smith-Magenis syndrome, cytosolic PEPCK deficiency and NMDA receptor glutamate insensitivity. Mol Genet Metab. 2014; 113:161-70. [PubMed: 24863970]

42. Allen AS, Berkovic SF, Cossette P, Delanty N, Dlugos D, Eichler EE, Epstein MP, Glauser T, Goldstein DB, Han Y, Heinzen EL, Hitomi Y, Howell KB, Johnson MR, Kuzniecky R, Lowenstein DH, Lu YF, Madou MR, Marson AG, Mefford HC, Esmaeeli Nieh S, O’Brien TJ, Ottman R, Petrovski S, Poduri A, Ruzzo EK, Scheffer IE, Sherr EH, Yuskaitis CJ, Abou-Khalil B, Alldredge BK, Bautista JF, Berkovic SF, Boro A, Cascino GD, Consalvo D, Crumrine P, Devinsky O, Dlugos D, Epstein MP, Fiol M, Fountain NB, French J, Friedman D, Geller EB, Glauser T, Glynn S, Haut SR, Hayward J, Helmers SL, Joshi S, Kanner A, Kirsch HE, Knowlton RC, Kossoff EH, Kuperman R, Kuzniecky R, Lowenstein DH, McGuire SM, Motika PV, Novotny EJ, Ottman R, Paolicchi JM, Parent JM, Park K, Poduri A, Scheffer IE, Shellhaas RA, Sherr EH, Shih JJ, Singh R, Sirven J, Smith MC, Sullivan J, Lin Thio L, Venkat A, Vining EP, Von Allmen GK, Weisenberg JL, Widdess-Walsh P, Winawer MR. Epi4K Consortium Epilepsy Phenome/Genome Project. De novo mutations in epileptic encephalopathies. Nature. 2013; 501:217-21. [PubMed: 23934111]

43. O'Roak BJ, Stessman HA, Boyle EA, Witherspoon KT, Martin B, Lee C, Vives L, Baker C, Hiatt JB, Nickerson DA, Bernier R, Shendure J, Eichler EE. Recurrent de novo mutations implicate novel genes underlying simplex autism risk. Nat Commun. 2014; 5:5595. [PubMed: 25418537]

44. de Ligt J, Willemsen MH, van Bon BW, Kleefstra T, Yntema HG, Kroes T, Vulto-van Silfhout AT, Koolen DA, de Vries P, Gilissen C, del Rosario M, Hoischen A, Scheffer H, de Vries BB, Brunner HG, Veltman JA, Vissers LE. Diagnostic exome sequencing in persons with severe intellectual disability. N Engl J Med. 2012; 367:1921-9. [PubMed: 23033978]

45. Yavarna T, Al-Dewik N, Al-Mureikhi M, Ali R, Al-Mesaifri F, Mahmoud L, Shahbeck N, Lakhani S, AlMulla M, Nawaz Z, Vitazka P, Alkuraya FS, Ben-Omran T. High diagnostic yield of clinical exome sequencing in middle eastern patients with mendelian disorders. Hum Genet. 2015; 134:967-80. [PubMed: 26077850]

46. Firth HV, Richards SM, Bevan AP, Clayton S, Corpas M, Rajan D, Van Vooren S, Moreau Y, Pettett RM, Carter NP. DECIPHER: database of chromosomal imbalance and phenotype in humans using ensembl resources. Am J Hum Genet. 2009; 84:524-33. [PubMed: 19344873]

47. Zhang Y, Kong W, Gao Y, Liu X, Gao K, Xie H, Wu Y, Zhang Y, Wang J, Gao F, Wu X, Jiang Y. Gene mutation analysis in 253 chinese children with unexplained epilepsy and intellectual/ Developmental disabilities. PLoS One. 2015; 10:e0141782. [PubMed: 26544041]

48. Zhu X, Petrovski S, Xie P, Ruzzo EK, Lu YF, McSweeney KM, Ben-Zeev B, Nissenkorn A, Anikster Y, Oz-Levi D, Dhindsa RS, Hitomi Y, Schoch K, Spillmann RC, Heimer G, Marek-Yagel D, Tzadok M, Han Y, Worley G, Goldstein J, Jiang YH, Lancet D, Pras E, Shashi V, McHale D, Need AC, Goldstein DB. Whole-exome sequencing in undiagnosed genetic diseases: interpreting 119 trios. Genet Med. 2015; 17:774-81. [PubMed: 25590979] 
49. Tarabeux J, Kebir O, Gauthier J, Hamdan FF, Xiong L, Piton A, Spiegelman D, Henrion É, Millet B, Fathalli F, Joober R, Rapoport JL, DeLisi LE, Fombonne É, Mottron L, Forget-Dubois N, Boivin M, Michaud JL, Drapeau P, Lafrenière RG, Rouleau GA, Krebs MO. S2D team. Rare mutations in N-methyl-D-aspartate glutamate receptors in autism spectrum disorders and schizophrenia. Transl Psychiatry. 2011; 1:e55. [PubMed: 22833210]

50. Grozeva D, Carss K, Spasic-Boskovic O, Tejada MI, Gecz J, Shaw M, Corbett M, Haan E, Thompson E, Friend K, Hussain Z, Hackett A, Field M, Renieri A, Stevenson R, Schwartz C, Floyd JA, Bentham J, Cosgrove C, Keavney B, Bhattacharya S, Hurles M, Raymond FL. Italian Xlinked Mental Retardation ProjectUK10K ConsortiumGOLD Consortium. Targeted NextGeneration sequencing analysis of 1,000 individuals with intellectual disability. Hum Mutat. 2015; 36:1197-204. [PubMed: 26350204]

51. Kenny EM, Cormican P, Furlong S, Heron E, Kenny G, Fahey C, Kelleher E, Ennis S, Tropea D, Anney R, Corvin AP, Donohoe G, Gallagher L, Gill M, Morris DW. Excess of rare novel loss-offunction variants in synaptic genes in schizophrenia and autism spectrum disorders. Mol Psychiatry. 2014; 19:872-9. [PubMed: 24126926]

52. Talkowski ME, Rosenfeld JA, Blumenthal I, Pillalamarri V, Chiang C, Heilbut A, Ernst C, Hanscom C, Rossin E, Lindgren AM, Pereira S, Ruderfer D, Kirby A, Ripke S, Harris DJ, Lee JH, Ha K, Kim HG, Solomon BD, Gropman AL, Lucente D, Sims K, Ohsumi TK, Borowsky ML, Loranger S, Quade B, Lage K, Miles J, Wu BL, Shen Y, Neale B, Shaffer LG, Daly MJ, Morton $\mathrm{CC}$, Gusella JF. Sequencing chromosomal abnormalities reveals neurodevelopmental loci that confer risk across diagnostic boundaries. Cell. 2012; 149:525-37. [PubMed: 22521361] 

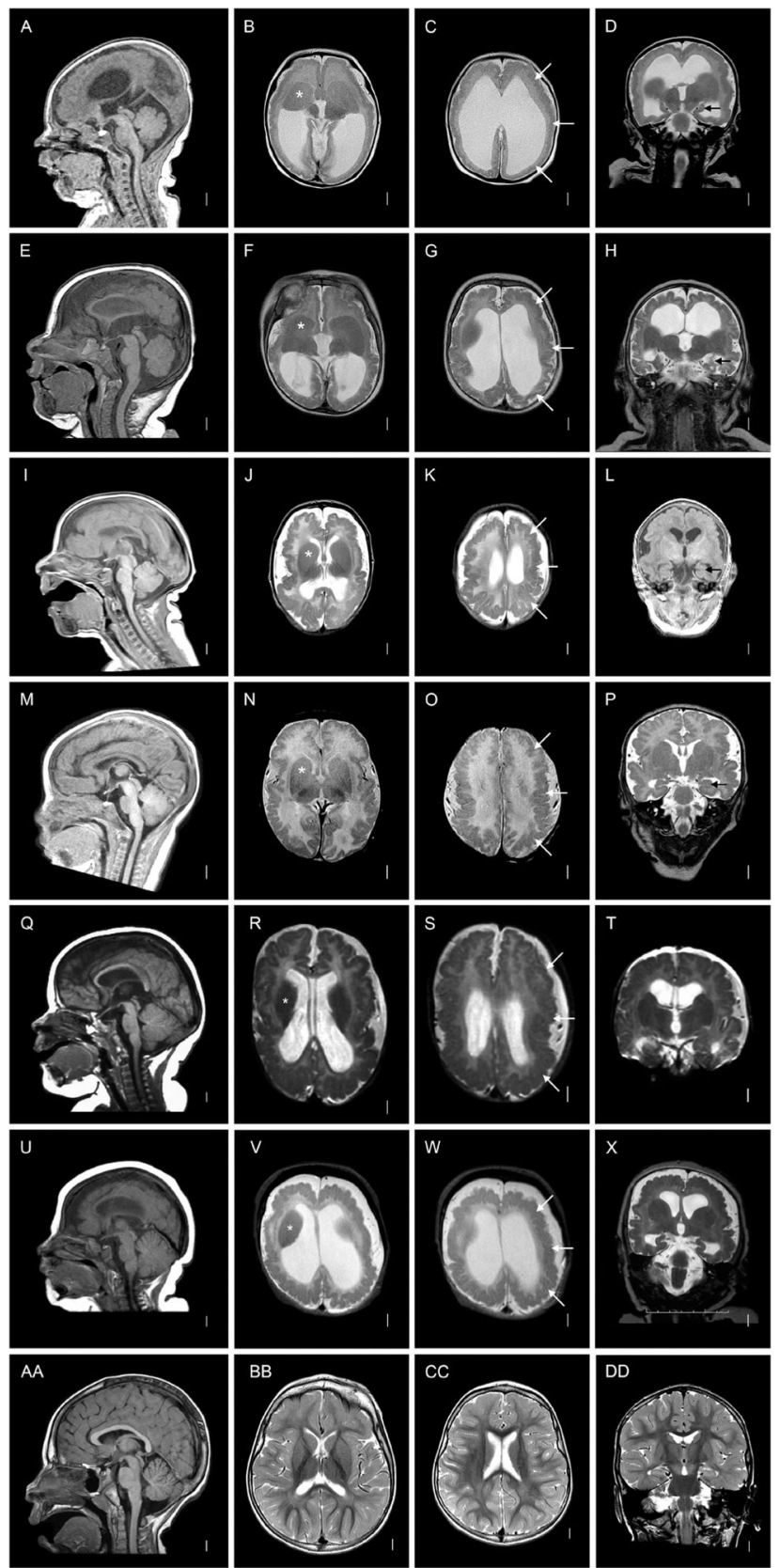

Figure 1.

MRI of patients with malformation of cortical development. MRI scans of patients $p$. (Ala639Val) (A-D), p.(Ser810Arg) (E-H), p.(Ile655Phe) (I-L), p.(Ala636Val) (M-P), p. (Arg693Ser) (Q-T), p.(Ser810Asn) (U-X), and a normal control (AA-DD) showing T1weighted mid-sagittal images (first column), T2-weighted axial images through the basal ganglia (second column) and higher lateral ventricles (third column), and T2-weighted coronal images through the hippocampus (fourth column). The mid-sagittal images are normal except for mildly low forehead in several subjects (A, I, U), although several are slightly off the midline. The lower axial images show relatively large and mildly dysplastic basal ganglia compared with normal (asterisks in B, (F, J, N, R and V)). All axial images 
(middle two rows) show a diffuse irregular gyral pattern with small gyri and limited intracortical microgyri (white arrows on the right side of images that point to the left hemispheres), an appearance intermediate between typical polymicrogyria and the cortical appearance of tubulinopathies. The coronal images show hippocampal dysplasia with thick leaves and open hilus, which varies from severe $(\mathrm{D}, \mathrm{H}, \mathrm{X})$ to moderate $(\mathrm{L}, \mathrm{P})$. 


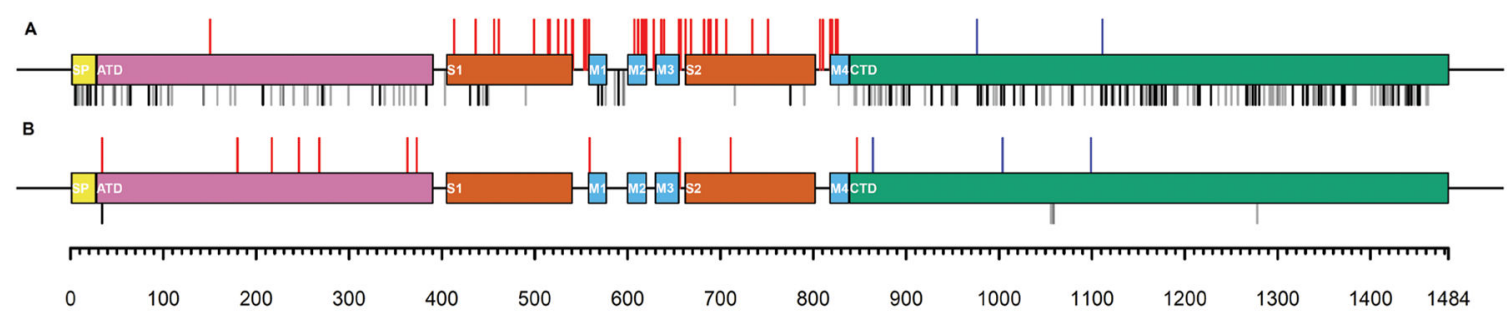

Figure 2.

De novo variants in GRIN2B. (A) Clustering of (likely) pathogenic missense variants in GRIN2B. All but one of the (likely) pathogenic missense variants cluster in the ligandbinding or transmembrane domains of GluN2B, which are regions with little to no benign missense variation in the control population. The de novo missense p.(Arg1111His) and the inframe deletion p.(Lys976del) in the CTD were classified as VUS. (B) Location of pathogenic truncating variants in GRIN2B. The recurrent variant c.99dupC, p.

(Ser34Gln $\left.f s^{*} 25\right)$ listed in ExAC is part of a homopolymer stretch of seven recurrent $\mathrm{C}$ nucleotides suggesting a technical artefact. Variants classified as VUS establish a premature termination codon in the last exon of $G R I N 2 B$, including a de novo truncating variant in a control individual p.(Arg1099Ala $f * 51) .{ }^{38}$ Red bars indicate pathogenic/likely pathogenic de novo variants. Blue bars indicate de novo VUS. Grey bars indicate single nucleotide variants (SNV) listed in one ExAC individual each. Black bars indicate SNV seen in more than one ExAC individual. ATD, amino-terminal domain; CTD, carboxy-terminal domain; ExAC, Exome Aggregation Consortium; M1-M4, transmembrane domain; S1, S2, ligandbinding domain; VUS, variants of unknown significance. 
?

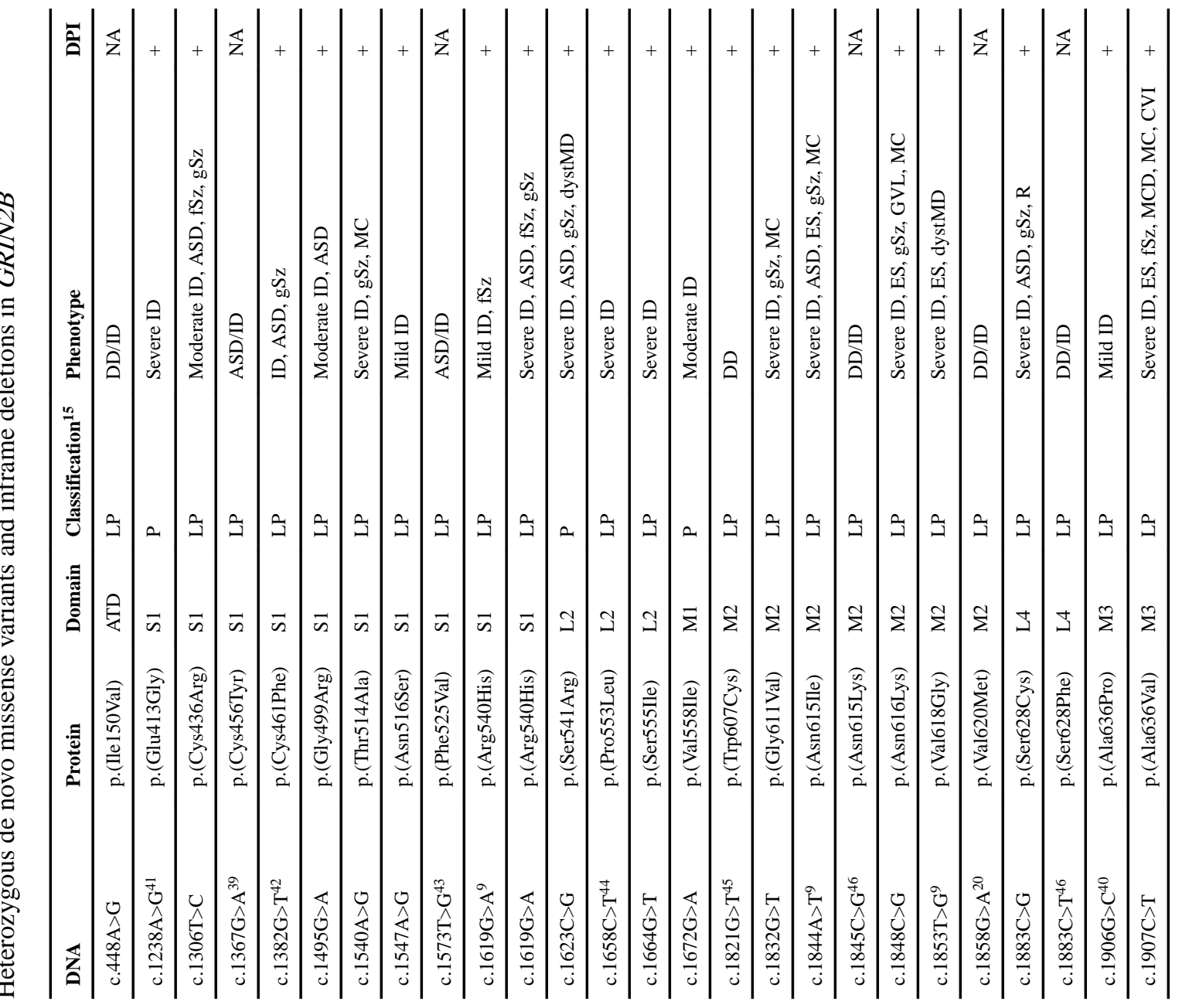

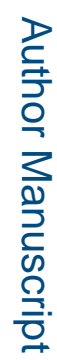


Platzer et al.

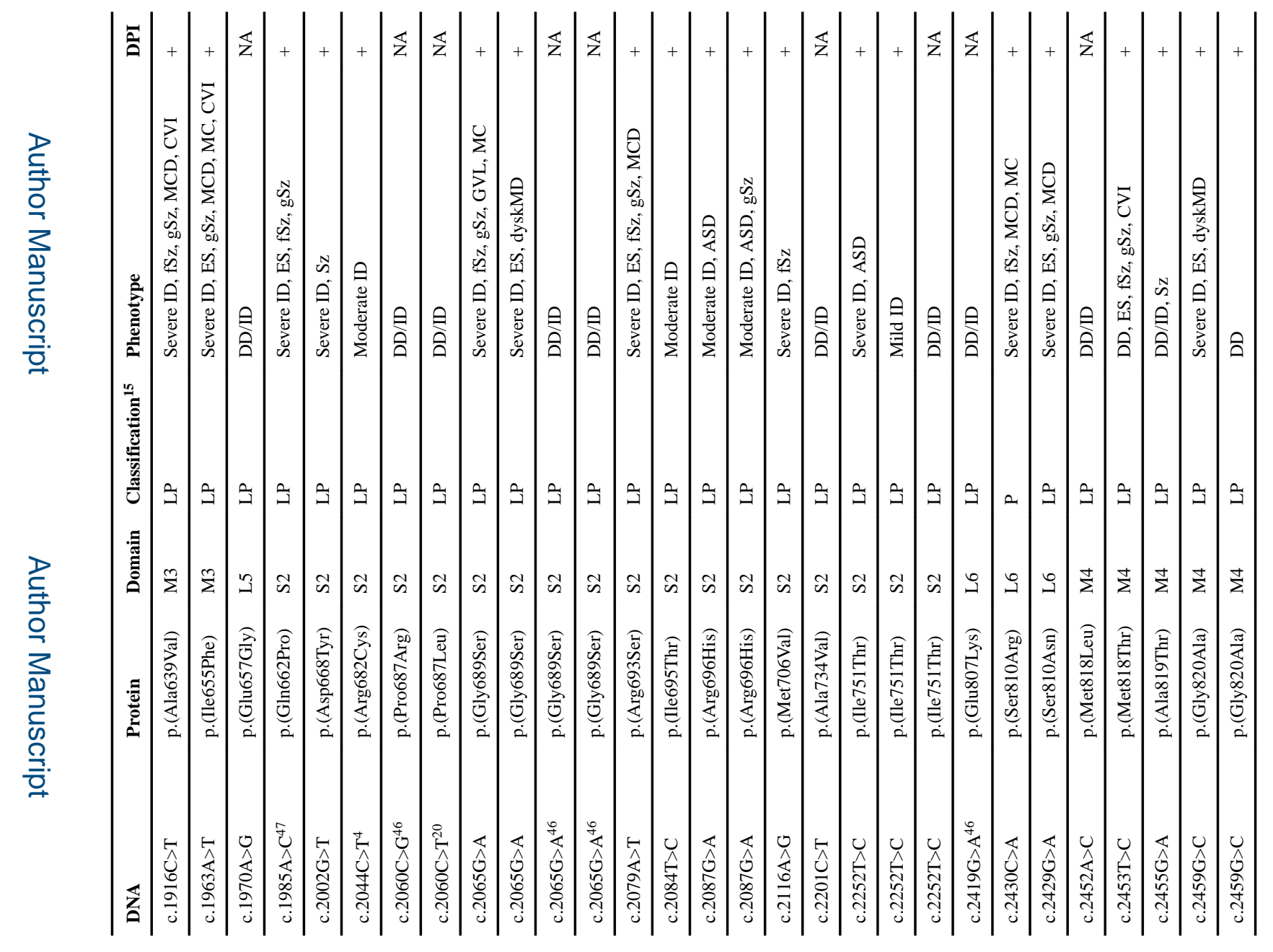

로을

를 


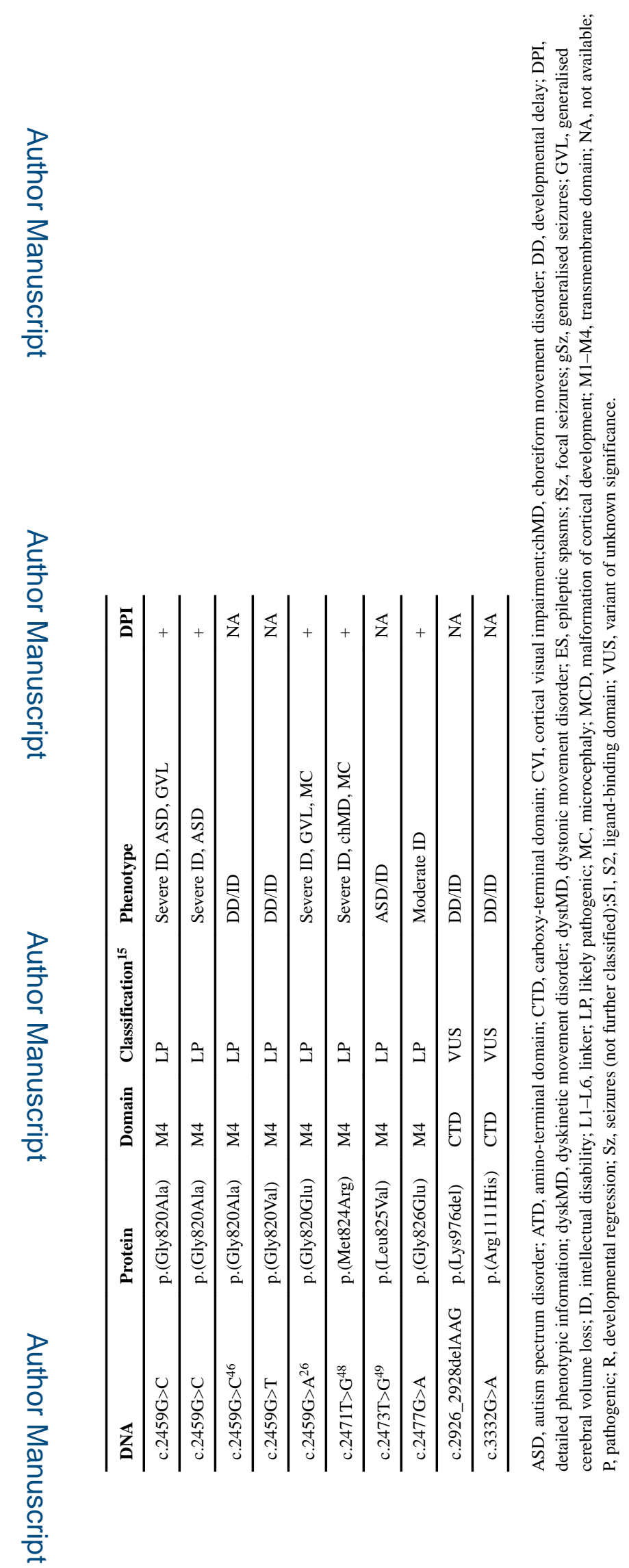

JMed Genet. Author manuscript; available in PMC 2017 October 25. 


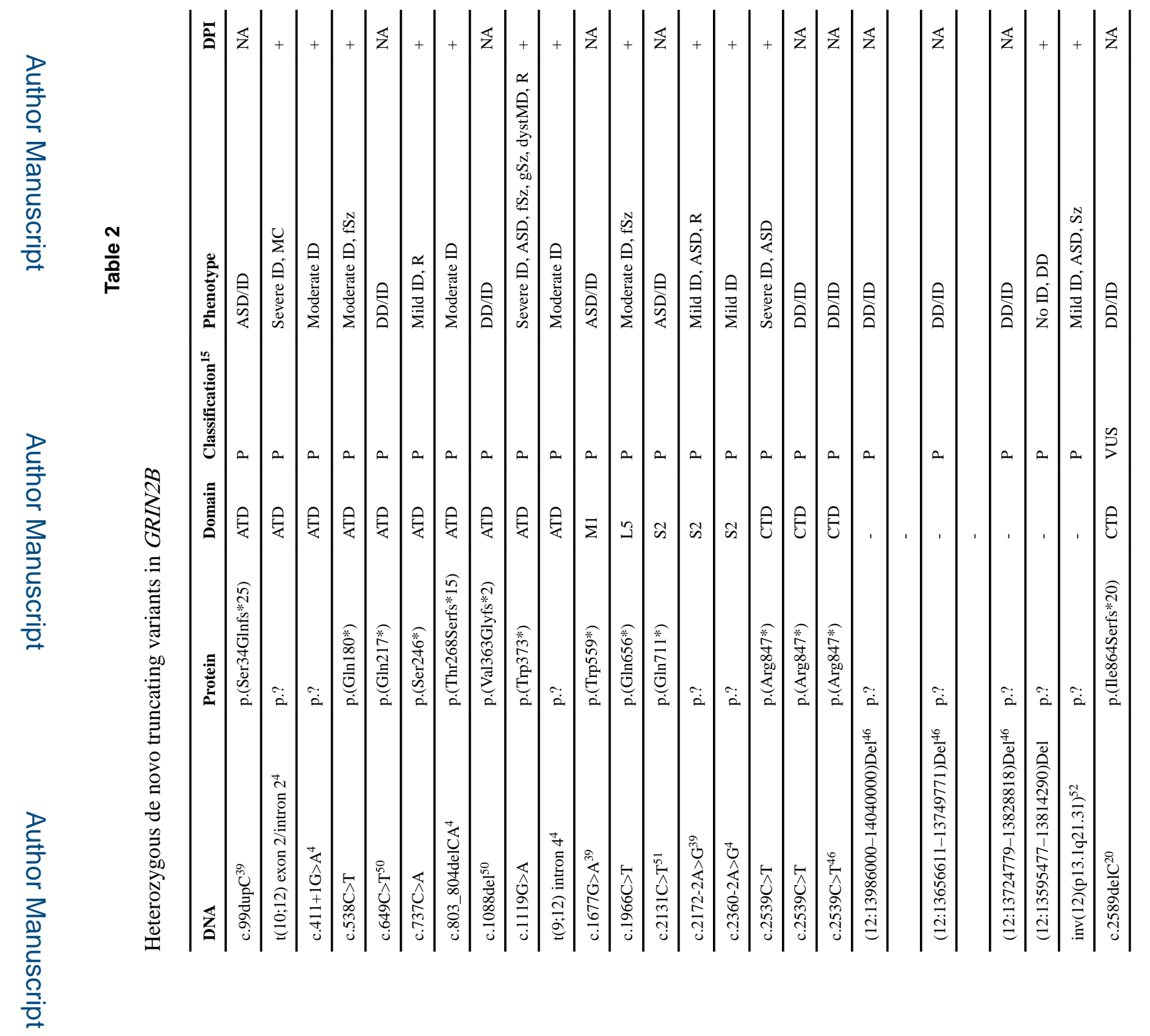

JMed Genet. Author manuscript; available in PMC 2017 October 25. 


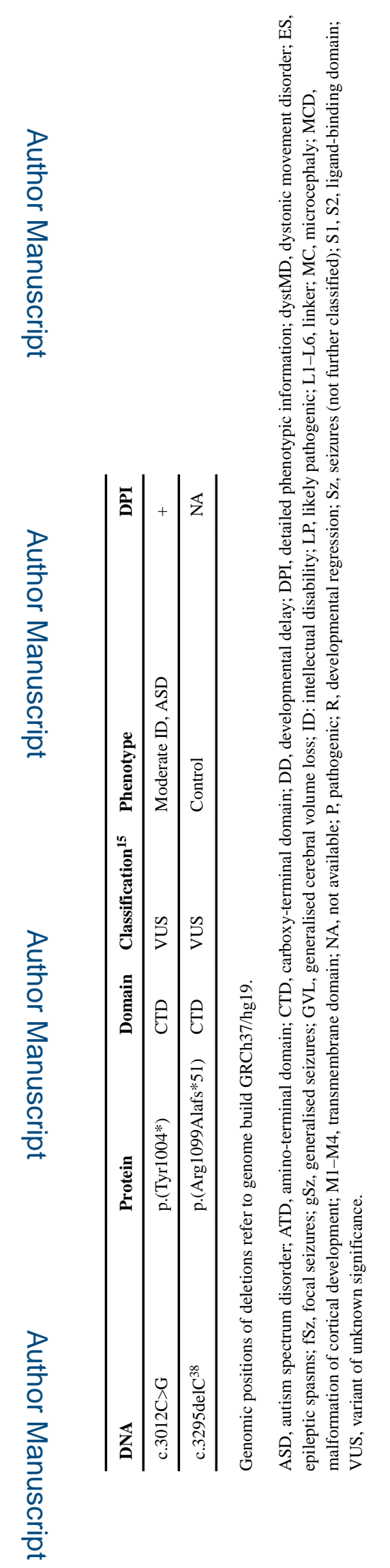

J Med Genet. Author manuscript; available in PMC 2017 October 25. 


\section{Table 3}

Summary of pharmacological data

\begin{tabular}{|c|c|c|c|c|}
\hline & Glu, $\mathrm{EC}_{50}, \mu \mathrm{M}(\mathrm{n})$ & Gly, $\mathbf{E C}_{50}, \mu M(n)$ & $\mathrm{Mg}^{2+}, \mathrm{IC}_{50}, \mu \mathrm{M}(\mathrm{n})^{*}$ & Proton, $\mathrm{I}_{\mathrm{pH} 6.8} /{ }_{\mathrm{IpH} 7.6} \%$ (n) \\
\hline WT 2B & $1.5 \pm 0.08$ & $0.35 \pm 0.02(41)$ & $25 \pm 2.7(33)$ & $15 \% \pm 0.5 \%$ \\
\hline S541R & $10 \pm 1.7(10)^{\dagger}$ & $1.0 \pm 0.15(9)^{\dagger}$ & $18 \pm 1.8(9)$ & $17 \% \pm 0.4 \%$ \\
\hline V558I & $4.2 \pm 0.8(6)^{\dagger}$ & $0.50 \pm 0.03$ & $26 \pm 6.2(6)$ & $13 \% \pm 0.2 \%(6)$ \\
\hline G611V & $1.7 \pm 0.1(8)$ & $0.33 \pm 0.02(6)$ & $>1000(8)^{\dagger}$ & $11 \% \pm 0.4 \%$ \\
\hline $\mathrm{I} 655 \mathrm{~F}$ & $5.6 \pm 0.60(7)^{\dagger}$ & $0.51 \pm 0.07(6)$ & $220 \pm 36(6)^{\dagger}$ & $67 \% \pm 2.6 \%(10)^{\dagger}$ \\
\hline M706V & $1.5 \pm 0.18(7)$ & $0.24 \pm 0.02(6)$ & $26 \pm 4.8(5)$ & $16 \% \pm 1.2 \%(6)$ \\
\hline S810R & $0.013 \pm 0.003(8)^{\dagger}$ & $0.027 \pm 0.03(7)^{\dagger}$ & $24 \pm 3.3(5)$ & $35 \% \pm 4.2 \%(8)^{\dagger}$ \\
\hline M818T & $0.37 \pm 0.07(10)^{\dagger}$ & $0.09 \pm 0.02(6)^{\dagger}$ & $29 \pm 8.0(8)$ & $47 \% \pm 4.1 \%(8)^{\dagger}$ \\
\hline A819T & $0.58 \pm 0.07(9)^{\dagger}$ & $0.09 \pm 0.02(6)^{\dagger}$ & $36 \pm 4.9(9)$ & $51 \% \pm 1.4 \%(6)^{\dagger}$ \\
\hline G820A & $1.6 \pm 0.23(6)$ & $0.35 \pm 0.04(8)$ & $21 \pm 4.8(7)$ & $10 \% \pm 0.21 \%(6)$ \\
\hline $\mathrm{L} 825 \mathrm{~V}$ & $1.3 \pm 0.2(9)$ & $0.36 \pm 0.07$ (5) & $35 \pm 3.6(10)$ & $14 \% \pm 0.7 \%$ \\
\hline
\end{tabular}

Mean \pm SEM (n).

The log of the $\mathrm{EC}_{50}$ and $\mathrm{IC}_{50}$ are normally distributed and were used in all statistical tests.

Holding at $-60 \mathrm{mV}$.

p $<0.05$ compared with corresponding wild-type (WT): one-way analysis of variance, Tukey post-hoc. 